\title{
Urban Marginalization and the Declining Capacity for Disaster Risks in Contemporary China
}

\author{
Jia Xu* (iD) and Makoto Takahashi \\ Geography Unit, Department of Social and Human Environment, Graduate School of Environmental Studies, \\ Nagoya University, Nagoya 464-8601, Japan; makoto.takahashi@nagoya-u.jp \\ * Correspondence: xujia_ouc@163.com
}

\begin{abstract}
Many disaster studies in the social sciences have so far pointed out that contemporary urbanization catalyzes the transformation of actual and potential risks into disasters. Compared with the greater attention paid to the losses of disasters, there is inadequate recognition of the roles of deep-seated social factors in addressing environmental changes and risks. In addition, very few discussions about social vulnerabilities have paid attention to China, even though they focus on developing countries. In the past four decades, China's rapid urbanization, urban expansions, and large-scale rural-urban migration have led to increasing difficulties in urban management, generating a large number of marginalized populations and spaces that are often called urban villages. The current marginalization problems are connected with economic poverty, sustained exclusion, and social inequality under state-managed urbanization. This study aims to provide a valuable discussion on the relationship between rapid urbanization and urban marginalization to identify the underlying causes of social vulnerability from the perspectives of institution, space, and urban governance, reviewing the experiences of China's urbanization. This study concludes that urbanization-induced marginalization has adverse impacts on structural resistance to external pressures such as natural disasters.
\end{abstract}

Citation: $\mathrm{Xu}, \mathrm{Jia}$, and Makoto

Takahashi. 2021. Urban

Marginalization and the Declining Capacity for Disaster Risks in Contemporary China. Social Sciences 10: 424. https://doi.org/10.3390/ socsci10110424

Academic Editor: Nigel Parton

Received: 8 September 2021

Accepted: 1 November 2021

Published: 4 November 2021

Publisher's Note: MDPI stays neutral with regard to jurisdictional claims in published maps and institutional affiliations.

Copyright: (c) 2021 by the authors. Licensee MDPI, Basel, Switzerland. This article is an open access article distributed under the terms and conditions of the Creative Commons Attribution (CC BY) license (https:// creativecommons.org/licenses/by/ $4.0 /)$.
Keywords: urbanization; marginalization; urban village; social vulnerability; disaster risk

\section{Introduction}

In the era of the risk society, with its distinct characteristics from other periods in history, human beings must cope not only with traditional risks, including natural disasters, public health concerns, industrial accidents, and social security (Kong et al. 2017) but also with the new challenges of population growth and aging, resource shortages, environmental pollution, climate change, ecological destruction, and so on. According to Beck (1992), who differentiated between dangers and risks, dangers have been known since the early history of mankind, for example, as a potential threat to life in natural catastrophes, while risks originate in decisions taken by man (Matten 2004). The potential harm from risks is an unintended side effect in the production of benefits (Battistelli and Galantino 2019), and ever-evolving and increasing risks are inextricably linked to urbanization. Moreover, in the context of the rapid process of social development, the transition from risk to disaster frequently occurs quickly and with little warning.

As the urbanization process accelerates, the uncertainty of risks is increasing (Wolsko and Marino 2016; Zhou and Zhao 2013; Zheng and Qi 2011). Although urbanization and industrial growth are often viewed as economically beneficial, they have the potential to harm the environment (Hussein and Ahmed 2016). Subsequently, environmental harm poses significant risks to urban areas and their inhabitants, exacerbating their vulnerabilities (Seto and Satterthwaite 2010). For example, there is evidence that fast urbanization and increasing megacities have resulted in the creation of extremely vulnerable urban populations, notably through informal settlements and poor land management practices (Garschagen and Romero-Lankao 2015). In the coming decades, rapid 
urbanization will be one of the greatest challenges to ensuring human well-being and the viability of global ecosystems (Redman and Jones 2005), in particular in Asia and Africa. Human interactions with extreme events can determine whether some phenomena merely pose hazards or will lead to substantial losses (Turner et al. 1996). Despite the hazard scale being small and quite local, catastrophe consequences can have negative repercussions on vulnerable individuals and communities, resulting in certain unforeseen losses (Sorrensen 2003).

China's urbanization has accelerated rapidly in the past 40 years via a complex sociospatial process. According to the National Bureau of Statistics of China in 2020 and China Floating Population Development Report in 2020, the most prominent manifestation is the agglomeration of the population in cities and the continuous expansion of urban space: Between 2004 and 2018, the built-up area in China increased from $30,400 \mathrm{~km}^{2}$ to $58,500 \mathrm{~km}^{2}$, which reflects the speed and scale of spatial expansion. And in 2019, for example, there were approximately 850 million permanent residents in the cities of China and the country's population mobility reached 247 million in 2020). Based on the data from United Nations in 2018 , it is predicted that more than $80 \%$ of the national population will live in urban areas by 2050. In the coming decades, this high coastal mobility among the population is expected to continue growing, while dramatic increases in population agglomeration and spatial expansion are forecasted in the central and western regions, which are currently underdeveloped.

To date, China's development has encountered enormous challenges. Urbanization in the form of an increase in spatial scale has long been considered a sign of economic vitality (Yuan 2007), and the GDP-oriented political assessment system of its regional and local governments has promoted the expansion of built-up areas. Rural land and communities surrounding the cities are quickly incorporated into the urban system, creating a unique space in the form of the urban village, which experiences a constant influx of labor migrants. This has led to a redistribution of space, wealth, and risk. With low priority policy concentration, these areas display the recognizable characteristics of instability and sensitivity in terms of population, society, and space. Compared with the growing academic debate about rural and urban disaster risk reduction (e.g., Wang et al. 2008; Zhai et al. 2014; Chan et al. 2017), the effects of urbanization on the vulnerability of these areas have not yet received sufficient attention.

With the irreversible increase in urban population and the continuous growth of urban space, disaster risk reduction (DRR) has increasingly become a core issue of social development. The reduction of disaster risk can through systematic efforts to identify and reduce the causes of disasters (UNISDR 2009). China is currently one of the most disaster-plagued countries in the world. As a result of the late start in the creation of disaster study, there is a scarcity of study on the impact of underlying societal causes on disaster risks, the present emphasis is still placed on physical sciences and engineering. Marginalization has also become an increasingly important issue in social development for the past few years (see Bacud 2018; Pongponrat and Ishii 2017). The concept can provide a more thorough understanding of specific vulnerabilities (e.g., Collins 2008; Poucki and Bryan 2014; Mitrović 2015), which are determined by physical, social, economic, and environmental factors or processes.

Thus, what kinds of relationships are there between urbanization, marginalization, and social vulnerability? What causes are deeply rooted in the urbanized society? To answer these questions, this study theoretically explores the root causes of social vulnerability in urban China by reviewing a variety of extant studies-both from within and outside of China-and by emphasizing the interaction of the spatial, demographic, institutional, and social elements of the country's urban system. The discussion is especially focused on the socio-spatial mechanisms of marginalization, aiming to help reduce vulnerability and strengthen the disaster prevention capabilities of urban society. The authors hope that China's experiences provide valuable contributions to theorizing the urban society and disaster risks from the perspective of a non-Western, rapidly urbanizing country. 
The remainder of this paper is organized as follows. Section 2 provides an overview of the most recent disaster research trends. Section 3 outlines the marginal places and populations in urban China and notes the importance of addressing marginalization. This is followed by discussions about the mechanisms of institutions, space, and governance in the process of rapid urbanization to underline the determinants of this marginalization. Section 5 highlights that solely the undergoing large-scale physical reconstruction of urban villages may erode sustainable development. Finally, the paper ends with the conclusions of the research and an account of the current outlook.

\section{Overview the Recent Trend of Disaster Studies in China}

From Figure 1, global research on disasters has seen a surge in the last 20 years. In China, an earthquake of magnitude 8 that occurred in Sichuan in 2008 with painful losses, followed by a series of deadly earthquake disasters, including the 2010 Yushu, 2013 Lushan, and 2014 Ludian earthquakes, opened the door to a leap forward in the development of China's disaster research. Henceforth, research on disaster prevention as an important subject has been conducted tangibly. There has been a significant increase in disaster studies in the last decade, however, the growth trend has been still slower than expected (Figure 1).

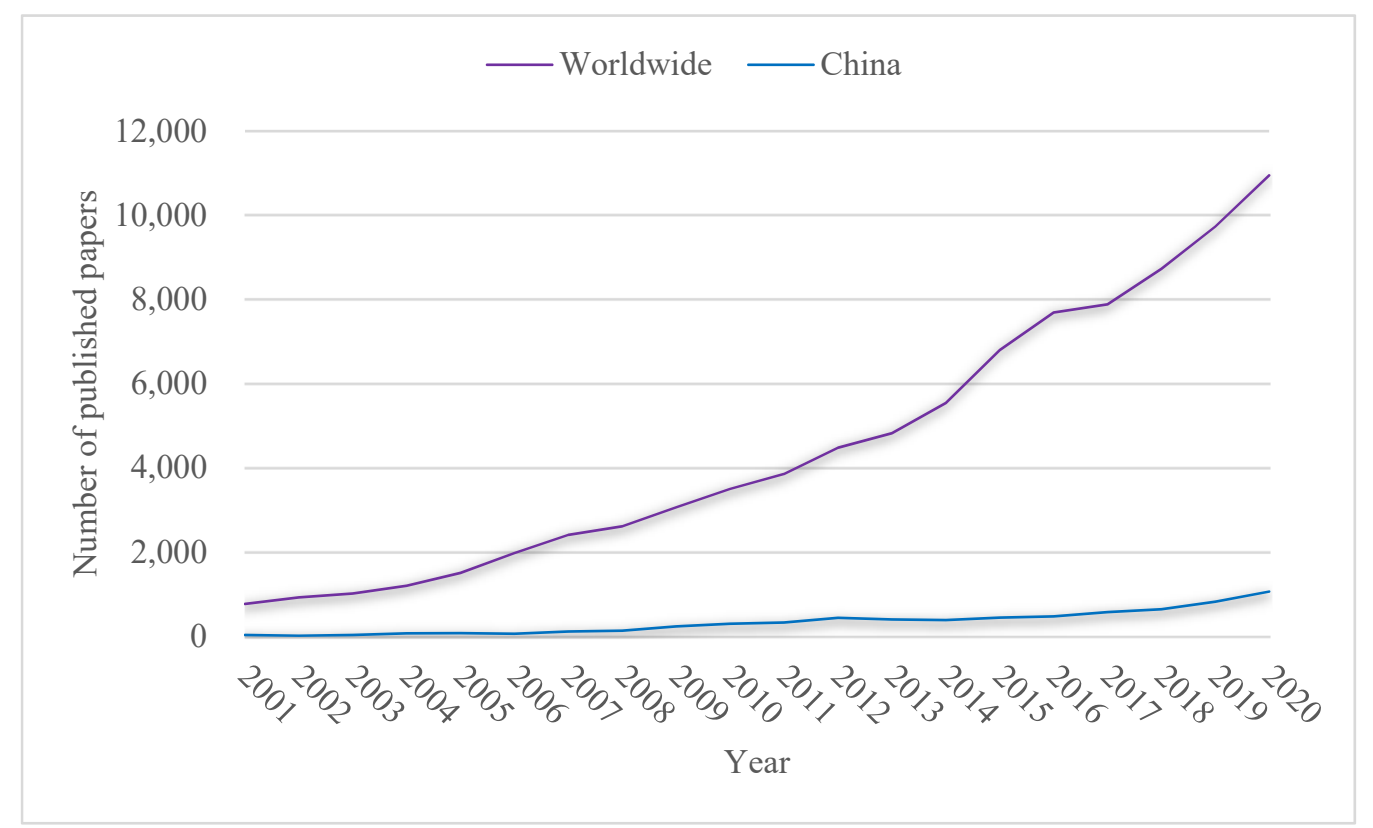

Figure 1. The number of disaster studies in China and the worldwide from 2001 to 2020 (Data source: Web of Science, Access date: 14 October 2021).

Until now, most of the research on disasters in China is based on natural sciences. As shown in Figure 2, the top three fields of Chinese disaster research are Geosciences Multidisciplinary, Environmental Sciences, and Water Resources, while there are only 125 papers published in economics, accounting for $2.3 \%$ of the total number of disaster research and only 123 papers in interdisciplinary Social Sciences, accounting for only $2.3 \%$ of the total number of disaster research.

Initially, disaster researchers and policymakers all over the world agreed that disaster risk management might be achieved through disaster engineering because of their availability to depict the scope and extent of disasters and evaluate the risk and susceptibility of buildings based on destructive capacities. Despite the fact that this research has given a better understanding of the physical mechanisms of natural hazards and engineering measurements of disaster prevention, however, natural scientists are often baffled as to why disaster losses continue to rise and why some places are disproportionately hit by disasters. Later studies discovered that disasters were caused not only by external risk pressures 
but also by particular social dynamics, and then "social vulnerability" be involved in disaster studies.

\begin{tabular}{|c|c|c|c|c|c|c|}
\hline $\begin{array}{l}1283 \\
\text { Geosciences Multidisciplinary }\end{array}$ & \begin{tabular}{|l}
872 \\
Meteorology Atmospheric \\
Sciences
\end{tabular} & $\begin{array}{l}256 \\
\text { Engineering } \\
\text { Electrical } \\
\text { Electronic }\end{array}$ & \begin{tabular}{|l|l}
228 \\
Engineering \\
Geological
\end{tabular} & \begin{tabular}{||l}
220 \\
Green \\
Sustaina \\
Science \\
Technole \\
Techno
\end{tabular} & & $\begin{array}{l}217 \\
\text { Engineering } \\
\text { Environmental }\end{array}$ \\
\hline \multirow[t]{2}{*}{$\begin{array}{l}1155 \\
\text { Environmental Sciences }\end{array}$} & $\begin{array}{l}346 \\
\text { Environmental Studies }\end{array}$ & $\begin{array}{l}212 \\
\text { Geography Physical }\end{array}$ & & \multirow[t]{2}{*}{\begin{tabular}{||l}
154 \\
Materials \\
Science \\
Multidisci- \\
plinary
\end{tabular}} & \multirow[t]{2}{*}{\begin{tabular}{|l|l}
146 \\
Imaging \\
Iccience \\
Photographic \\
technology
\end{tabular}} & \begin{tabular}{||l}
133 \\
Energy \\
Fuels
\end{tabular} \\
\hline & \multirow[t]{2}{*}{$\begin{array}{l}343 \\
\text { Remote Sensing }\end{array}$} & \multirow{2}{*}{\multicolumn{2}{|c|}{\begin{tabular}{|l}
208 \\
Public Environmental \\
Occupational Health
\end{tabular}}} & & & \\
\hline \multirow{3}{*}{$\begin{array}{l}973 \\
\text { Water Resources }\end{array}$} & & & & \multirow{2}{*}{\multicolumn{2}{|c|}{\begin{tabular}{|l}
128 \\
Multidisciplinary \\
Sciences
\end{tabular}}} & 123 \\
\hline & \multirow{2}{*}{$\begin{array}{l}302 \\
\text { Enginering C Civil }\end{array}$} & \multirow{2}{*}{\multicolumn{2}{|c|}{$\begin{array}{l}189 \\
\text { Computer Science } \\
\text { Information Systems }\end{array}$}} & & & \begin{tabular}{|l} 
Sciences \\
Interdisci
\end{tabular} \\
\hline & & & & \multicolumn{2}{|l|}{$\begin{array}{l}125 \\
\text { Economics }\end{array}$} & \\
\hline
\end{tabular}

Figure 2. The number of articles in different fields of disaster studies in China from 2011 to 2020 (Data source: Web of Science, Access date: 14 October 2021).

Since the 1980s, Western academic circles have been conducting extensive studies on social vulnerability to disasters, turning to the perspective of social processes and risk distribution (Hewitt 1983) and are concerned more with the structural factors of human society that are affected by disasters, emphasizing that vulnerability is a state that exists before disasters (Zhou 2012). In terms of qualitative research, sociologists and geographers (for example, Adger and Kelly 1999; Wisner et al. 2004; Bolin 2007; Alexander 2012; Aldrich 2019; Tierney 2019) have explained how social factors influence or shape the exposure, sensitivity, and adaptive capacity of various societies and populations. For quantitative research, the research that has an important guiding role is Cutter et al. (2003), who, focusing on Georgetown County, used county-level socioeconomic and geographical data to divide the Social Vulnerability Index (SoVI) into multiple dimensions. Then, Vincent (2004) created an index assessing the relative vulnerability of social systems to climate-change-induced variations on a cross-national scale. Later, more researchers (for example, Rygel et al. 2006; Balica 2007; Flanagan et al. 2011; Armas and Gavris 2013) further assessed the social vulnerability of different regions and different groups. In the past 20 years, based on the findings of a significant number of qualitative and quantitative studies, the theoretical framework of social vulnerability has gradually improved (Pelling 2003; Adger 2006).

In China, however, disaster research has mostly focused on changes in precipitation patterns and temperature, models for disaster prediction and risk assessment, and disaster risk analysis in the context of climate change over the last 10 years (See Figures 2 and 3). Although the number of vulnerability studies is increasing to a certain extent, physical vulnerability is still the main concern. Social vulnerability research, both theoretical and practical, has received little attention.

To summarize, disaster research has progressed steadily over the past 20 years internationally, but China's key study topics remain concentrated in the natural sciences, and disaster research from the perspective of social sciences is severely weak. In fact, depending solely on physical science to predict natural disaster events and their consequences is extremely difficult, particularly in light of present climate change and rising extreme weather. There are a few studies on the social perspective, including, for example, Zhang et al. (2013) discussing the progress of community-based disaster management from the applied perspective, but before this, we argue that more emphasis in China should be paid to vulnerability studies from the standpoint of social sciences. Furthermore, vulnerability research needs to be tailored to the unique characteristics of particular places 
and fields (Khazai et al. 2014). Therefore, it is also necessary to deeply understand the specific socio-spatial contexts combined with the physical conditions before conducting assessments and proposing disaster prevention policies. This is also the original intention of this article.

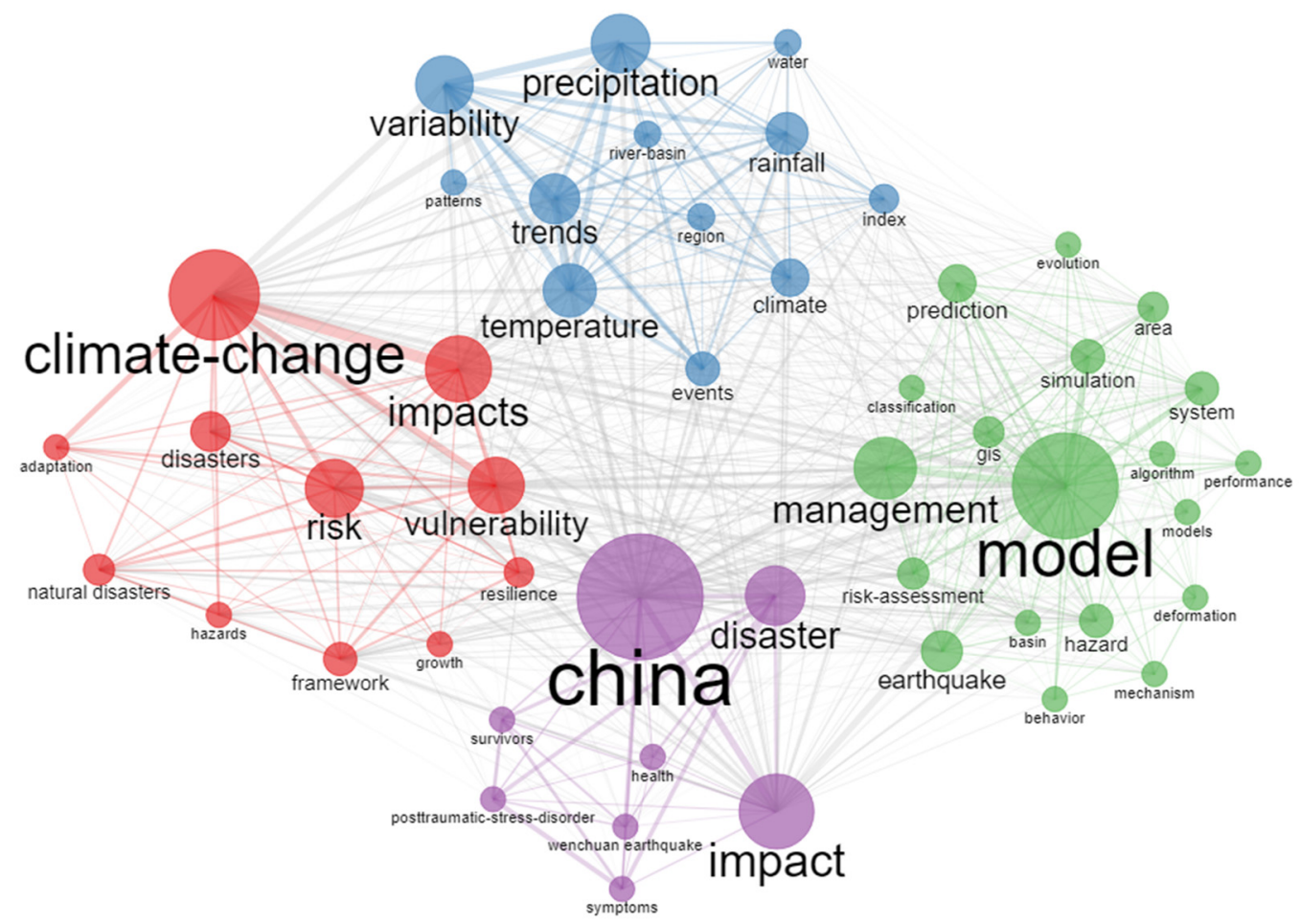

Figure 3. Main topics of disaster research in China from 2011 to 2020 (Data source: Web of Science, Access date: 14 October 2021).

\section{Marginalization Created by Rapid Urbanization}

Each society produces and maintains its own marginality (Dangschat 2009) and has its own respective places and populations of such marginality (Lefèbvre 1991). The concept of "marginality" remains a frequently discussed topic in geographical studies, encompassing a wide spectrum of phenomena from remote rural regions to disadvantaged urban populations (Bernt and Colini 2013). Marginalization includes key indicators that contribute to vulnerability, such as political, social, and economic powerlessness and disadvantage (Billson 2005); more concretely, it refers to sustained exclusion, social inequality, and economic poverty. Moreover, it can emerge in regions experiencing a process of growth, such as Asia and Africa, or those undergoing a shrinking process, as in European countries (e.g., Lang 2012; Bernt and Colini 2013). In fact, marginalization demonstrates great socio-spatial variety; therefore, it also represents uneven spatial development. Space provides a place for powers, interests, ideas, and other elements but also exacerbates the social differentiation and conflicts hidden behind urban expansion and population movement. The transformation and differentiation of space results in marginalization. The geographical notions of "marginalization" and "marginality" are very close to the meaning of "peripheralization" (see Danson and de Souza 2012); such peripheries can be situated within the geographical area of a city, a region, a country, or on their fringes (Kühn 2015).

The marginality of Chinese society has been somewhat created by its rapid urbanization. Unlike the market-oriented urbanization of Western countries, China's urbanization was controlled by the state from 1949 to 1978. After 1978, the influence of state planning shrank, and a market process based on the state plan began to evolve, transforming China's internal growth models and opportunities. Although this kind of "plan-plus-market system" has facilitated rapid social development, it has also become a driving mechanism for the creation of marginalized places and populations (Qi 2004). At the beginning of 
the country's reform and opening up in the 1980s, the national government implemented preferential policies in the eastern coastal cities to encourage their prioritized development. This led to an imbalance in the growth of the eastern coastal and inland regions at the national level, mobilizing rural resources to support urban development, which created marginalized areas at the regional level. Marketization has widened the gap between the rich and the poor, leading to the emergence of vulnerable groups. This kind of socio-spatial heterogeneity, arising from policy disparity and reorganization, represents the essence of China's marginalization process. It appears in every process of spatial expansion and social mobility, as well as in the construction of new social relations.

\subsection{Marginal Places in Urban China}

With the development of globalization, China has been transformed into the industrial factory of the world's economy (Cassiers and Kesteloot 2012). Foreign direct investment has created employment opportunities that attract rural-urban migrants to the eastern coastal cities, which, in turn, stimulates the boom of urban economies. To provide ample space for urban development, the government relies heavily on the transformation of rural spaces to urban spaces, and this land-use strategy has brought considerable benefits to cities and stimulated rapid urban growth and urban sprawl. The spatial disparity induced by the flow of capital-controlled resources is manifested as a "center-periphery" phenomenon: The center region of a city continuously absorbs advantageous resources, such as population, intelligence, and wealth (Tang and Shen 2019), while many villages in geographically peripheral areas of mega-urban regions take in a large number of migrants and become spaces for cheap labor reproduction.

Saunders (2012) called these places where migrants enter the city "Arrival City," while Chinese scholars have generally described them as "urban villages" or villages in cities. This kind of place is a combination of rural and urban systems and incorporates huge hidden veins of disaster risk, marked by high building density, undefined rights and obligations for management, environmental degradation, and inadequate provision of social infrastructure. The complex social and environmental realities brought about by the long-term urban-rural divide have meant that these areas are often ignored in the formation of the development agendas.

Urban villages in China are a country-wide phenomenon. They initially emerged in the mega-cities along the southeastern coast, such as Shanghai and Guangzhou. With the implementation of a new national strategy to develop Western China in the 2000s, a modernization program spanning from the coast to the interior areas has resulted in large-scale population movements and spatial restructurings in the hinterland (Song 2014). At present, urban villages are commonly found in almost all large and medium-sized cities in China.

\subsection{Vulnerable Populations and Urban Deprivation}

The emergence of vulnerable groups is a direct reflection of the negative consequences of rapid urbanization. The largest vulnerable group comprises low-skilled and low-paid rural-urban migrants who appeared in the era of China's market economy and currently totals nearly 300 million. Over the past 40 years, this group has made substantial contributions to China's economic growth; however, its cities cannot provide them with adequate economic, knowledge, or power resources. Additionally, many obstacles to their social rights and welfare are imposed by the dichotomous household registration system (Hukou), which allows them to live only in informal settlements in high-risk locations where they lack access to emergency services. As such, social and institutional factors shape migrants' socio-economic instability while continuing to generate new urban poverty.

Contemporary urban poverty differs from traditional poverty in terms of economic considerations. It is closely connected to marginalization and entails far more than low income since, in market-based economies, a lack of income is significantly correlated with other causes of poverty and is a predictor of future deprivation issues (Wratten 1995). In 
the book Urban Outcasts, Wacquant (2008) proposed a definition of new urban poverty that encompassed the occupational dualization and resurgence of inequality (macro-social), the de-socialization of wage labor (economic), the retreat of the social state (political), and concentration and defamation (spatial). Adger (1999) held that access and entitlement to resources, which affects both baseline vulnerability and coping capacity with the impacts of extreme events, may become the key to understanding urban poverty. The poor do not have a voice in politics and are deprived of opportunities in economic activities, despised by other people, and vulnerable to external forces: The unavailability of resources undermines their capacity to withstand the impact of external pressure and eventually results in urban poverty. In short, in China's urban society, migrants are on the margins of the economic, the social, and the institutional (Xu and Takahashi 2021), while the scale and depth of this urban marginality are underestimated by governments and society.

\subsection{Socio-Spatial Heterogeneity: The Interaction between Space and Society}

Much of the theorizing of space in human geography has largely accepted it as being relational, and geographic endeavors have moved from engagement with fixed or static space to more dynamic notions of space, such as socio-spatial relations. Space is thereby inextricably linked to society (Bachmann 2016). Marginalization in geographical study can be approached from the perspective of the socio-spatial redistribution of hazard risks. In the progress of urbanization, with its associated urban sprawl, the land-use patterns of rural areas are increasingly embedded in urban systems.

The original spatial structure is reconstructed, resulting in a new spatial form that produces an enduring effect on social differentiation and the uneven distribution of exposure to hazard risks. Thus, disadvantaged populations are pushed into a hazardous environment in urban areas, for example, living in unsafe buildings, on unstable slopes, or on low-lying land. Such geographical segregation is the projection of social structure onto space (Cassiers and Kesteloot 2012): It often overlaps and interacts with social, economic, and political factors to constrain individual or collective opportunities and capacities, which are related to vulnerable groups' access to livelihood and ability to cope with, recover from, and prepare for external pressures.

Socio-spatial unevenness created by enduring rapid development increases susceptibility and diminishes the adaptive capacity of a society to cope with the impact of hazards. This unevenness can be measured with certain indicators of marginalization, such as poverty, ethnicity, exclusion, and inequity. From the community perspective, the Sendai framework for DRR 2015-2030 also aims to tackle the underlying drivers of disaster risk, including the consequences of poverty and inequality and the marginalization of certain groups, to reduce vulnerabilities and prevent risks (Stein and Walch 2017). Therefore, whether disaster studies focus on preparedness, mitigation, or management, it is important to explore the social vulnerability resulting from the marginalization phenomenon.

\section{Driving Factors of Marginalization in Chinese Urban Society}

\subsection{Institutional Limitation and Inequality}

In general, the common features of urbanization include the migration of a population from rural to urban areas and the conversion of land from agricultural to non-agricultural uses. Compared to Western countries, China's experience of urbanization began later, via a state-led model. China's unique dual land ownership and dual household registration systems are the key institutional arrangements for realizing its government-led urbanization. This duality relates to a widespread economic phenomenon in developing countries, in which the agricultural sector, based on traditional production methods, and the industrial sector, based on modern production methods, coexist with each other (Bian 2017). Urban villages are a result of the dual land ownership system and, in this sense, differ from the slum spaces created in a wide range of developing countries in the process of urbanization, regardless of the similarities in landscape. 
China's rural-urban migrants are restricted by the dual household registration system and are emerging as a disadvantaged societal group in terms of wage payment, health care, and education. Due to the urban-rural dichotomy, while urban villages and their inhabitants join the city spatially, in reality, they are excluded from the urban society, especially in terms of public service and management systems. Thus, the long-standing institutional inequality between urban and rural areas is the fundamental reason for the negative effects of urbanization in China.

In terms of its population structure, China is a traditional agricultural country, and its people have long depended on the land to survive. In the current transition period, the majority of the population still comprises farmers whose livelihoods rely on agriculture. The limitations of land systems have become the root cause for (re)producing social vulnerability and restricting the development of contemporary Chinese society. As far as land ownership is concerned, urban land has historically been owned by the state, and rural land has typically experienced a transition from private ownership to communal ownership: The Constitution of 1982 stipulates that the land in the city belongs to the state, while rural and suburban land is collectively owned. The property rights of urban land can circulate in the market, which controls its price. However, rural land cannot be used for purposes other than agriculture, and it cannot be purchased or sold without authorization. Even so, China's government has increasingly decided to take its agricultural land out of productive use but has held a speculative investment or transferred it to other uses for the secondary industry and service sector. As the market values increase, the gains benefit local wealth or state interests (Pelling and Mustafa 2010). By constructing a dual system of land, the government transfers rural production factors to cities in the form of unequal exchange to provide sources or funds for industrialization and urbanization. This is generally argued to be a primitive accumulation of capital ( $\mathrm{Xu}$ 2016); through such a primitive accumulation of capital, the rapid development of urbanization has been realized.

In the period before the reform and opening up, in particular from 1958 to 1978, the household registration system imposed strict limitations on population movement, which hindered the pace of urbanization in China. Gradually, from the 1980s onward, the income factor has become a pulling force encouraging the surplus labor in rural areas to move to urban areas. Owing to their low education and skill levels, such rural-origin laborers can usually only find jobs with low pay and poor conditions in the secondary labor market. Notably, in the eastern coastal areas of China where the migrant population is most intensively concentrated, surveys have demonstrated that the wages for low-level labor have not risen in the past 10 years due to the serious surplus of cheap labor under the market mechanism (Wen 2020). There are also few opportunities for upward mobility available to them.

The household registration system prevents many rural migrants from settling permanently in cities. Subject to the dual urban-rural system, the local government only provides some public services to city registration holders, and rural migrants are not given access to the state-provided social welfare to which urban residents are normally entitled. Moreover, a household's hukou was/is inherited by the next generation; consequently, hukou status and, thereby, the educational attainment and eventually employment opportunities of the next generation of rural populations, are still restricted by birth. Thus, the hukou system has evolved from a formal institution that previously contained rural-urban migration to one that now controls spatial mobility indirectly (Afridi et al. 2015). For two reasons, we argue that it is unlikely that the social disparity created by the household registration system will be overcome in the short term. First, the land system and the household registration system are closely interrelated: In the course of China's history, both have consistently played roles in restricting the flow of population and stabilizing the social order. Second, in the current regime, the household registration system is bundled with social welfare, such as employment, health care, education, and so on, and assumes the functions of welfare distribution and social security. 


\subsection{The Lack of Spatial Justice}

Space constitutes the social and material conditions for the survival and development of the people who reside within it whilst also being an important means of urban development and the consolidation of national society. With the development of modernization, space is no longer simply regarded as a static container but has gradually become a tool of capitals, powers, and interests. Through space, the power class realizes capital accumulation, distributes labor, and organizes various flows (including those of population and resources). To overcome the lack of capitalist development momentum, capital converts space into commodity, and infinite capital accumulation necessitates the continual opening up of fresh room (Harvey 2001). This economically focused, benefit-oriented space occupancy thus becomes the driving force of class differentiation.

Based on Max Weber's theory of "class and life chances", geographers have further emphasized that space is not only an expression of social structure but also a major factor in its reconstruction (Ying 2017). On the one hand, as the market value of space rises, the domestic property class grows exponentially, widening the gap between the rich and the poor (Saunders 2012). Residents in impoverished areas, on the other hand, are unable to build effective social networks within the community or preserve their own quality of life, escape poverty, or participate in the power structure. In this manner, denying disadvantaged groups spatial rights reflects society's structural function and hierarchical inequalities.

In urban spatial systems, living spaces tend to be basic units. Housing justice is the embodiment of civil rights in the allocation of space resources. In 1998, China initiated reforms of the housing system, converting dwellings from distributable capital to private properties, and gated communities gained overwhelming prevalence in the housing market (Wu et al. 2014). Although such gated and access-restricted communities have long been a presence in industrialized cities, they have emerged as a common form of urbanization in the cities of developing-countries and have created new forms of social exclusion (Seto et al. 2010).

Due to their limited ability to choose their housing, low- and middle-income migrants typically tend to concentrate in urban villages. In the Pearl River Delta, for example, large cities such as Shenzhen and Guangzhou have seen the development of hundreds of urban villages that provide affordable housing for millions of migrant workers (Ren 2013). In other developing countries and regions, there are also spaces similar to urban villages. In general, the inhabitants of these villages live either in self-built shanty areas on squatter ground or are accommodated in public property (Zhou 2014). In urban villages, housing is provided based on the relationship between the original villagers and the tenants (the bulk of the floating population). This kind of residential relationship means that migrants to cities move rapidly and find it difficult to become permanent residents there. This creates greater challenges for urban management, including disaster risk reduction.

In China, rapid urbanization has driven the appreciation of urban land, triggered by urban planning and the ongoing investment in infrastructure. The disproportionately high land price prevents the government from providing social welfare, including guaranteed housing, which continues to increase spatial differentiation and create a vicious circle of poverty. The trend of new urban poverty that is induced by unemployment, low wages, insecurity, and migration has gradually expanded from the Pearl River Delta that the fastest-growing region since the 1980s to the eastern coastal areas and large, inland cities. To a certain extent, the increased population mobility caused by spatial injustice will intensify the spread of risk across the country and could become a key issue threatening the sustainable development of Chinese cities in the future.

\subsection{Uncertainty in Urban Governance: Changes from Danwei to Community}

In the Chinese context, governance can be described as a mechanism that embodies the coordination and relationship between the state and society (Wu 2002) and is also widely advocated as one of the essential components in reducing disaster risk (Gall et al. 2014). 
Urban governance processes are critical for a wider understanding of regional and global environmental concerns in local urban decision making (Seto and Satterthwaite 2010), and how the occurrence and spread of disasters are reduced or prevented through urban governance directly affects the future of cities and societies.

It is worth mentioning that each community occupies a central position in state-society relations, playing an active role in the constitution and governance of society and providing a path ahead in the face of rising social fragmentation, life opportunities, and expectations (Raco and Flint 2001). The concept of "community" is no longer limited solely to the issue of the provision of services and welfare but extends to include culture, health, environment, education, and grassroots democracy. Compared with the Western notion of community, the community (shequ) in China holds a very specific, government-defined meaning and function (Ren 2013) and is renamed from the two lowest levels of urban governance: the Street Office (jiedaoban) and the Residents' Committee (juweihui).

Before the development of community, from the establishment of the communist government to the 1990s, danwei (work-unit) radically transformed the socio-spatial landscape as the core constituent of urban China. The system very closely related a residence to a workplace which were virtually owned by the state in the cities and was a Chinese-specific socialist form in terms of power, subjectivity, and space (Bray 2005). Danwei served as a highly collectivized mode of production and consumption against a backdrop of resource scarcity, and its organization was manifested as the state's overall control, upon which individuals were highly dependent (Liu and Chai 2012). We observed that the danwei system had profound significance for urban governance in the course of China's history, while also detrimentally affecting contemporary urban development and risk management since some traditions are hard to shake off. During the danwei period, social life, economic production, and administrative management were highly unified; the state had enhanced its power in urban planning and community governance and established a State-Danwei-Individual vertical management system. After the disintegration of danwei, the new urban communities have been nominally self-governed, although, in fact, both their technology and financial support still come from the government. Top-down control is always adopted in the emergency management of urban communities; therefore, the community lacks initiative and room for spontaneity on major issues. This process can also be seen in instances of marginalization in which an individual or a group has lost some decision-making power (Déry et al. 2012).

Another important issue in urban governance is community participation and networks, which are vital components of the concept of governance (Dekker and van Kempen 2004). The process of creating a network is critical because it may foster community cohesiveness and mutual aid, therefore increasing community resilience (Djalante et al. 2011). As mentioned above, in the period of planned economy up until the early 1980s, China's urban society was managed by danwei and characterized as homogeneous, featuring the low population mobility and tight social networks of the acquaintance society. Since the 1980s, the economic reforms and disintegration of danwei have generated an increase in social/spatial mobility and class differentiation, which has been reflected in the fragmentation of residential spaces and the differences in lifestyle between various social groups (Chai et al. 2013). The dissolution of the danwei system has caused the spatial separation of the city's production and living activities, and neighbors have lost the bridging social capital that could help them to obtain information and resources. Consequently, the relationships of the acquaintance society have become a so-called "stranger community" with declining social trust and the loss of the sense of co-responsibility.

The specific institutional arrangement of China's household registration system has remained an "invisible wall" between urban and rural areas. However, a large number of rural migrants have still flowed into the city, and the long-closed urban society cannot legally and institutionally guarantee their participation in the management of urban communities, resulting in their social marginalization. In recent years in China, it has become widely recognized that a local government and/or a community-based organization should 
have a broader vision of community participation in order to enhance urban resilience and the sustainability of communities; however, in reality, the government continues to ignore the need to review the long-standing issues of social inclusion and exclusion in specific urban-rural boundaries (Song 2014).

Since the Sendai Framework 2015, the importance of communities in disaster risk reduction has been well acknowledged. In the case of disasters, people at the community level are the first to be exposed to the impacts of hazardous events (Pandey and Okazaki 2005). Community-based disaster reduction efforts are most successful when they involve the direct participation of the people at risk in the planning, decision making, and operational activities at all levels of responsibility (Zubir and Amirrol 2011). However, in China, the lack of coordination between urban governance and economic growth stages leads to the insufficient endogenous strength of the urban community, a lack of capacity to respond to crises, and an increase in the risks and/or losses of disaster.

\section{Can Rebuilding Urban Villages Promote the Sustainability of Urban Society?}

Disaster risk is one of the biggest challenges for the sustainable development of contemporary urban China. Given that rapid urbanization has spawned a large number of marginalized and disadvantaged groups, the policies of DRR must take root causes of social vulnerability into account. Political factors define the responsibilities and rights that play a key role in shaping risky circumstances. However, for the government, there are conflicts of interest between economic surplus, environmental protection, resource exploitation, and social welfare (Walker 1989). Effective governance can enhance urban environmental sustainability, while ineffective governance could increase vulnerability. McGranahan et al. (2001) argued that in being confronted by a wealth of development issues and planning dilemmas, policymakers are in danger of not seeing the policy "wood" for the contextual "trees". For a long time, urban villages have been considered to be the most hazardous space in cities; therefore, under the impetus of the government, Chinese cities have launched a huge transformation policy for urban villages over the past 20 years to solve their poor ecological conditions and backward infrastructure. This transformation is not intended to shape a stable and unique internal socio-ecological system of urban villages but rather for the expansion of new industrial and commercial land through demolition and rebuilding, such as the construction of executive real estate and the renewal of urban CBDs. The development of housing and other economic sectors has ignited the municipal and local governments' enthusiasm due to their contribution to GDP growth, on which local officials are evaluated (Ong 2014).

By renting houses in urban villages, marginalized urban residents try to organize their livelihood activities (e.g., casual labor, street trading, crafts, etc.) in the big city neighborhoods (Wisner et al. 2004); indeed, they are not deemed to bear the expense of infrastructure. In the context of the increasing demand for urban resources and facilities, the long-term occupancy of urban villages in the city space has resulted in insufficient land for industrial development and housing construction. The rebuilding of urban villages may benefit the government, developers, and homeowners but not the flowing population. Even if extreme conflicts arise, they are likely to end up in negotiations for compensation between other stakeholders and the homeowners (Zhu 2014). To some extent, rebuilding can certainly reduce hazard exposure due to the new, reinforced buildings and infrastructure; however, reconstruction holds no value for the vulnerable floating population. Due to the governance of space dictated by the power and price determination in the market, the net result caused by such rebuilding is that the living space of marginal people is reduced, forcing their relocation and even pushing them into more hazardous environments ( $\mathrm{Xu}$ and Takahashi 2021). If a dangerous place is the closest this population can get to economic opportunities with lower rents, marginal people will locate there almost regardless of the risk (Hardoy and Satterthwaite 1989). As such, vulnerable populations increasingly tend to be exposed to hazards and insecurity as a result of the rebuilding of urban villages. 
Although the negative influences of urban villages are emphasized in urban planning, they have substantial, if not always positive, implications, such as providing affordable housing for migrants while also promoting the reproduction of cheap labor. If only demolition is adapted to achieve transformation, the result will exacerbate social problems, such as poverty and unemployment, thus undermining the capacity of disaster risk reduction. We argue, therefore, that it is more important for the Chinese government to enhance community resilience through efforts to involve socio-spatial marginalized people and to organize community-based disaster risk reduction than to devote itself to reconstruction projects.

\section{Conclusions and Outlook}

This study illustrates the marginalization phenomenon in urban China, combined with a focus on the unique institutional, spatial, and social dynamics of specific landscapes and populations. The marginalization processes that are triggered by urbanization influence the capacity of structural resistance to external pressures such as natural hazards and social insecurity. Social polarization, spatial exclusion, and the failure of community development, all of which are closely linked to the mechanism of institutions, space capital, and governance, are shaping the vulnerability of the current development of Chinese society.

First, the institutional arrangement is the most significant root cause of the creation and/or recreation of vulnerability and determines the distribution of resources, assets, and income. In constructing the basic structures of society, adapting to evolving conditions, and improving collective capacities, China's institutional arrangement has essential implications; however, due to its hysteresis of transition, it often results in obstacles. To respond to the emerging risks associated with rising capital intensity and population movement, new institutions are needed.

Second, spatial inequality restricts accessibility to the stable living space of migrants and, subsequently, not only increases hazard exposure but also molds them as passive and incapable in the face of risks such as hydrometeorological hazards or epidemics. It is thus critical to promote the rationalization of housing prices and to build public housing in Chinese cities.

Additionally, the role of a community-based approach in urban governance and risk management has been grossly underestimated. The challenge for urban communities is the reconfiguration of responsibilities and the opening up of decision-making to greater participation. Further research is needed to understand how shequ prevents migrants from participating in network building since only the maximum involvement of marginalized people can move community participation from rhetoric to reality. As vaguely disreputable, marginalized places, urban villages are not merely an urban spatial phenomenon but also a social system that accommodates a large number of vulnerable groups. Their evolutionary process involves spatial, social, and political spheres. Currently, the local governments in Chinese urban areas are recklessly encouraging the clearance and reconstruction of urban villages without adequately perceiving how marginalization is created or recreated, which is a huge barrier to urban risk management.

The perspective that highlights the root causes of social vulnerability by focusing on the phenomenon of marginalization is relatively recent, and there has been little related debate to date in China. Incorporating an examination of multiple factors would be significant in helping to identify problems and find solutions for disaster risk reduction. It would also contribute to the recognition of the urban village as a special kind of community and an inevitable outcome of rapid urbanization, as well as providing a better understanding of the populations most at risk in this process. This topic is expected to enrich the awareness of urgent global issues, such as the future of urban migration, the affordability of emerging big cities, and the creation of resilient communities. Today, with growing urban pressure and risks, there is a need to conduct multidisciplinary research to reduce the vulnerability of such minority groups and enhance their resilience. 
Author Contributions: Conceptualization, J.X. and M.T.; quantitative analysis, J.X.; writing-original draft preparation, J.X.; writing-review and editing, J.X. and M.T.; visualization, J.X. and M.T.; supervision, M.T.; project administration, J.X. and M.T.; funding acquisition, M.T. All authors have read and agreed to the published version of the manuscript.

Funding: The first author acknowledges China Scholarship Council for granting the scholarship to support the research. The research is supported by JSPA Grant-in-Aid for Scientific Research (B), Project Number 19H01381, with the second author as a principal investigator.

Data Availability Statement: Not applicable.

Conflicts of Interest: The authors declare no conflict of interest.

\section{References}

Adger, W. Neil. 1999. Social Vulnerability to Climate Change and Extremes in Coastal Vietnam. World Development 27: 249-69. [CrossRef]

Adger, W. Neil. 2006. Vulnerability. Global Environmental Change 16: 57-63. [CrossRef]

Adger, W. Neil, and Mick P. Kelly. 1999. Social vulnerability to climate change and the architecture of entitlements. Mitigation and Adaptation Strategies for Global Change 4: 253-66. [CrossRef]

Afridi, Farzana, Sherry Xin Li, and Yu-Fei Ren. 2015. Social Identity and Inequality: The Impact of China's Hukou System. Journal of Public Economics 123: 17-29. [CrossRef]

Aldrich, P. Daniel. 2019. Black Wave: How Networks and Governance Shaped Japan's 3/11 Disasters. Chicago: The University of Chicago Press.

Alexander, David. 2012. Disability and disaster. In The Routledge Handbook of Hazards and Disaster Risk Reduction. Edited by Ben Wisner, Jean-Christophe Gaillard and Ilan Kelman. New York: Routledge, pp. 413-23.

Armas, Iuliana, and Alexandru Gavris. 2013. Social vulnerability assessment using spatial multi-criteria analysis (SEVI model) and the Social Vulnerability Index (SoVI model)_A case study for Bucharest, Romania. Natural Hazards and Earth System Sciences 13: 1481-99. [CrossRef]

Bachmann, Veit. 2016. Spaces of Interaction: Enactments of Sociospatial Relations and an Emerging EU Diplomacy in Kenya, Territory, Politics. Governance 4: 75-96. [CrossRef]

Bacud, Susan T. 2018. Integration of Indigenous and Scientific Knowledge in Disaster Risk Reduction: Resilience Building of a Marginalized Sampaguita Growing Community in the Philippines. Procedia Engineering 212: 511-18. [CrossRef]

Balica, Stefania Florina. 2007. Development and Application of Flood Vulnerability Indices for Various Spatial Scales. In Water Science and Engineering. Delft: UNESCO-IHE MSc.

Battistelli, Fabrizio, and Maria Grazia Galantino. 2019. Dangers, Risks and Threats: An Alternative Conceptualization to the Catch-All Concept of Risk. Current Sociology 67: 64-78. [CrossRef]

Beck, Ulrich. 1992. Risk Society: Towards a New Modernity. London: Sage.

Bernt, Matthias, and Laura Colini. 2013. Exclusion, Marginalization and Peripheralization. Conceptual Concerns in the Study of Urban Inequalities. Working Paper. Erkner: Leibniz Institute for Regional Development and Structural Planning. Available online: www.irs-net.de/download/wp-exclusion-marginalization-peripheralization.pdf (accessed on 16 August 2020).

Bian, Jing. 2017. Reforming the Urban-Rural Dual Land System, Promoting the Equal Exchange of Land Elements. Contemporary Economic Management 39: 1-6. [CrossRef]

Billson, Janet Macini. 2005. No owners of soil. Redefining the concept of marginality. In Marginality, Power and Social Structure: Issues in Race, Class and Gender Analysis. Edited by Rutledge Melvin Dennis. Oxford: Routledge, pp. 29-47.

Bolin, Bob. 2007. Race, Class, Ethnicity, and Disaster Vulnerability. In Handbook of Disaster Research. Edited by Havidán Rodríguez, Enrico Louis Quarantelli and Russell Rowe Dynes. New York: Springer, pp. 113-29.

Bray, David. 2005. Social Space and Governance in Urban China: The Danwei System From Origins to Reforms. Stanford: Stanford University Press.

Cassiers, Tim, and Christian Kesteloot. 2012. Socio-Spatial Inequalities and Social Cohesion in European Cities. Urban Studies 49: 1909-24. [CrossRef]

Chai, Yan-Wei, Tian-Bao Liu, Na Ta, and Yan-Peng Xiao. 2013. A New Framework of Urban Danwei System Study in China. Human Geography 28: 1-6. [CrossRef]

Chan, Emily Ying Yang, Chun-Lan Guo, Po-Yi Lee, Si-Da Liu, and Carman Ka Man Mark. 2017. Health Emergency and Disaster Risk Management (Health-EDRM) in Remote Ethnic Minority Areas of Rural China: The Case of a Flood-Prone Village in Sichuan. International Journal of Disaster Risk Science 8: 156-63. [CrossRef]

Collins, Timothy William. 2008. The Political Ecology of Hazard Vulnerability: Marginalization, Facilitation and the Production of Differential Risk to Urban Wildfires in Arizona's White Mountains. Journal of Political Ecology 15: 21-43. [CrossRef]

Cutter, Lynn Susan, Bryan J. Boruff, and Lynn W. Shirley. 2003. Social vulnerability to envi- ronmental hazards. Social Science Quarterly 84: 242-61. [CrossRef] 
Dangschat, S. Jens. 2009. Space Matters-Marginalization and Its Places. International Journal of Urban and Regional Research 33: 835-40. [CrossRef]

Danson, Mike, and Peter de Souza. 2012. Periphery and Marginality: Definitions, Theories, Methods and Practice. In Regional Development in Northern Europe. Peripherality, Marginality and Border Issues. Edited by Mike Danson and Peter de Souza. Abingdon: Routledge, pp. 1-15.

Dekker, Karien, and Ronald van Kempen. 2004. Urban Governance within the Big Cities Policy. Cities 21: 109-17. [CrossRef]

Déry, Steve, Walter Leimgruber, and Walter Zsilincsar. 2012. Understanding Marginality: Recent Insights from a Geographical Perspective. Hrvatski Geografski Glasnik 74: 5-18. [CrossRef]

Djalante, Riyanti, Cameron Holley, and Frank Thomalla. 2011. Adaptive Governance and Managing Resilience to Natural Hazards. International Journal of Disaster Risk Science 2: 1-14. [CrossRef]

Flanagan, E. Barry, Edward W. Gregory, Elaine J. Hallisey, Janet L. Heitgerd, and Brian Lewis. 2011. A Social Vulnerability Index for Disaster Management. Journal of Homeland Security and Emergency Management 8: 1-22. [CrossRef]

Gall, Melanie, Susan Lynn Cutter, and Khai Hoan Nguyen. 2014. Governance in Disaster Risk Management. Report number: AIRDR Report No. 3. Affiliation: Integrated Research on Disaster Risk. Geneva: United Nations Office for Disaster Risk Reduction. [CrossRef]

Garschagen, Matthias, and Patricia Romero-Lankao. 2015. Exploring the Relationships between Urbanization Trends and Climate Change Vulnerability. Climatic Change 133: 37-52. [CrossRef]

Hardoy, Jorge Enrique, and David Satterthwaite. 1989. Squatter Citizen: Life in the Urban Third World. London: Earthscan.

Harvey, David. 2001. Spaces of Capital: Towards a Critical Geography. Edinburgh: Edinburgh University Press, New York: Routledge.

Hewitt, Kenneth. 1983. Interpretations of Calamity from the Viewpoint of Human Ecology. London: Allen and Unwin.

Hussein, Muawya Ahmed, and Hanaa Mahmoud Sid Ahmed. 2016. Socio-environmental Impacts of Urban Expansion: Case of Arab Countries. International Journal of Applied Business and Economic Research 14: 7689-706.

Khazai, Bijan, Tina Kunz-Plapp, Christian Büscher, and Antje Wegner. 2014. VuWiki: An Ontology-Based Semantic Wiki for Vulnerability Assessments. International Journal of Disaster Risk Science 5: 55-73. [CrossRef]

Kong, Feng, Li-Li Lu, and Yi-Fei Wang. 2017. Preliminary Study of the Relationship between New Risk Factors and Traditional Risk Factors-Taking the Relationship between the Population Urbanization and Natural Disasters in China's County-level Administrative Units for Example. Journal of Anhui Agriculture Science 45: 157-61. (In Chinese)

Kühn, Manfred. 2015. Peripheralization: Theoretical Concepts Explaining Socio-Spatial Inequalities. European Planning Studies 23: 367-78. [CrossRef]

Lang, Thilo. 2012. Shrinkage, Metropolization and Peripheralization in East Germany. European Planning Studies 20: 1747-54. [CrossRef]

Lefèbvre, Henri. 1991. The Production of Space. Oxford: Blackwell.

Liu, Tian-Bao, and Yan-Wei Chai. 2012. The Meaning, Content and Prospect of Danwei System Research in the Perspective of Geography. Progress in Geography 31: 527-34. (In Chinese) [CrossRef]

Matten, Dirk. 2004. The impact of the risk society thesis on environmental politics and management in a globalizing economyprinciples, proficiency, perspectives. Journal of Risk Research 7: 377-98. [CrossRef]

McGranahan, Gordon, Pedro Jacobi, Jacob Songsore, Charles Surjadi, and Marianne Kjéllen. 2001. The Citizens at Risk: From Urban Sanitation to Sustainable Cities. London: Earthscan.

Mitrović, Luka Veselin. 2015. Resilience: Detecting Vulnerability in Marginal Groups. Disaster Prevention and Management: An International Journal 24: 185-200. [CrossRef]

Ong, H. Lynette. 2014. State-Led Urbanization in China: Skyscrapers, Land Revenue and 'Concentrated Villages'. The China Quarterly 217: 162-79. [CrossRef]

Pandey, Bishnu, and Kenji Okazaki. 2005. Community Based Disaster Management: Empowering Communities to Cope with Disaster Risks. Available online: http://unpan1.un.org/intradoc/groups/public/documents/un/unpan020698.pdf (accessed on 15 September 2020).

Pelling, Mark. 2003. The Vulnerability of Cities: Natural Disasters and Social Resilience. London: Reprinted by Earthscan.

Pelling, Mark, and Daanish Mustafa. 2010. Vulnerability, Disasters and Poverty in Desakota Systems. Discussion paper. Research for Development Outputs. Available online: https://assets.publishing.service.gov.uk/media/57a08bba40f0b652dd000e52/ Desakota-Part-II-B.pdf (accessed on 12 April 2020).

Pongponrat, Kannapa, and Sari Kayoko Ishii. 2017. Social Vulnerability of Marginalized People in Times of Disaster: Case of Thai Women in Japan Tsunami 2011. International Journal of Disaster Risk Reduction 27: 133-41. [CrossRef]

Poucki, Sasha, and Nicole Bryan. 2014. Vulnerability to Human Trafficking among the Roma Population in Serbia: The Role of Social Exclusion and Marginalization. Journal of Intercultural Studies 35: 145-62. [CrossRef]

Qi, Gong. 2004. An Analysis of the Emergence of "Marginalization" as a Social Mechanism in a Transitional Period. Theory Journal 120: 118-23. (In Chinese) [CrossRef]

Raco, Mike, and John Flint. 2001. Communities, Places and Institutional Relations: Assessing the Role of Area-Based Community Representation in Local Governance. Political Geography 20: 585-612. [CrossRef]

Redman, L. Charles, and Nancy S. Jones. 2005. The Environmental, Social, and Health Dimensions of Urban Expansion. Population and Environment 26: 505-20. [CrossRef]

Ren, Xue-Fei. 2013. Urban China. Cambridge: Policy Press. 
Rygel, Lisa, David O'Sullivan, and Brent Yarnal. 2006. A method for constructing a social vulnerability index: An application to hurricane storm surges in a developed country. Mitigation and Adaptation Strategies for Global Change 11: 741-64. [CrossRef]

Saunders, Doug. 2012. Arrival City: How the Largest Migration in History is Reshaping Our World. Shanghai: Shanghai Translation Publishing House. (In Chinese)

Seto, Ching-Yee Karen, and David Satterthwaite. 2010. Interactions between Urbanization and Global Environmental Change. Current Opinion in Environmental Sustainability 2: 127-28. [CrossRef]

Seto, Ching-Yee Karen, Roberto Sánchez-Rodríguez, and Michail Fragkias. 2010. The New Geography of Contemporary Urbanization and the Environment. Annual Review of Environment and Resources 35: 167-94. [CrossRef]

Song, Jing. 2014. Space to Maneuver: Collective Strategies of Indigenous Villagers in the Urbanizing Region of Northwestern China. Eurasian Geography and Economics 55: 362-80. [CrossRef]

Sorrensen, L. Cynthia. 2003. Frontier Spaces of Vulnerability: Regional Change, Urbanization, Drought and Fire Hazard in Santarém, Pará, Brazil. Urban Ecosystems 6: 123-44. [CrossRef]

Stein, Sabrina, and Colin Walch. 2017. The Sendai Framework for Disaster Risk Reduction as a Tool for Conflict Prevention. New York: The Social Science Research Council.

Tang, Mei-Li, and Ting Shen. 2019. The Four-layered Theoretical Characteristics of Space Justice and Its Contemporary Enlightenment. Journal of Jiangsu Administration Institute 103: 91-96. (In Chinese)

Tierney, Kathleen. 2019. Disasters: A Sociological Approach. Cambrige: Polity Press.

Turner, Robert Kelly, Susan Subak, and Neil W. Adger. 1996. Pressures, Trends, and Impacts in Coastal Zones: Interactions between Socioeconomic and Natural Systems. Environmental Management 20: 159-73. [CrossRef]

UNISDR. 2009. 2009 UNISDR Terminology on Disaster Risk Reduction. Geneva: United Nations International Strategy for Disaster Reduction (UNISDR). Available online: https://www.unisdr.org/files/7817_UNISDRTerminologyEnglish.pdf (accessed on 12 September 2020).

Vincent, Katharine. 2004. Creating an Index of Social Vulnerability to Climate Change for Africa. Working Paper 56. Anglia: Tyndall Centre for Climate Change Research and School of Environmental Sciences, University of East Anglia.

Wacquant, Loïc. 2008. Urban Outcasts: A Comparative Sociology of Advanced Marginality. Cambridge: Polity Press.

Walker, Jack. 1989. Introduction: Policy Communities as a Global Phenomena. Governance 2: 1-4. [CrossRef]

Wang, Jing-Ai, Pei-Jun Shi, Xiang-Sheng Yi, Hui-Cong Jia, and Lai-Yin Zhu. 2008. The Regionalization of Urban Natural Disasters in China. Natural Hazards 44: 169-79. [CrossRef]

Wen, Tie-Jun. 2020. Deconstructing Modernization. Beijing: The Oriental Press. (In Chinese)

Wisner, Ben, Piers Blaikie, Terry Cannon, and Ian Davis. 2004. At Risk: Natural Hazards, People's Vulnerability and Disasters. London: Routledge.

Wolsko, Christopher, and Elizabeth Marino. 2016. Disasters, Migrations, and the Unintended Consequences of Urbanization: What's the Harm in Getting out of Harm's Way? Population and Environment 37: 411-28. [CrossRef]

Wratten, Ellen. 1995. Conceptualizing urban poverty. Environment \& Urbanization 7: 11-33. [CrossRef]

Wu, Fu-Long. 2002. China's Changing Urban Governance in the Transition Towards a More Market-Oriented Economy. Urban Studies 39: 1071-93. [CrossRef]

Wu, Cai-Wei, Yong-Ping Wei, and Mark Yaolin Wang. 2014. Planned Gated Communities in Urban China. In Transforming Chinese Cities. Edited by Mark Yaolin Wang, Pookong Kee and Jia Gao. New York: Routledge, pp. 188-210.

Xu, Jing-Yong. 2016. A Study on Negative Effects and the Reform Paths of China's Dual Urban-rural Land System. Southeast Academic Research 2016: 110-19. (In Chinese) [CrossRef]

Xu, Jia, and Makoto Takahashi. 2021. Progressing vulnerability of the immigrants in an urbanizing village in coastal China. Environment, Development and Sustainability 23: 8012-26. [CrossRef]

Zhang, Xi, Li-Xin Yi, and Dong Zhao. 2013. Community-based disaster management: A review of progress in China. Natural Hazards 65: 2215-39. [CrossRef]

Ying, Li-Cheng. 2017. Space as a Sociological Perspective: The Orientations and Limitations of Spatial Interpretation. Sociological Review of China 5: 11-22. (In Chinese)

Yuan, Fei. 2007. Urban Expansion and Its Environmental Impact Analysis Using High Resolution Remote Sensing Data: A Case Study in the Greater Mankato Area. Available online: http:/ / www.asprs.org/a/publications/proceedings/tampa2007/0082.pdf (accessed on 11 August 2020).

Zhai, Guo-Fang, Sha-Sha Li, and Jing Chen. 2014. Reducing Urban Disaster Risk by Improving Resilience in China from a Planning Perspective. Human and Ecological Risk Assessment: An International Journal 21: 1206-17. [CrossRef]

Zheng, Zhao-Pei, and Shan-Zhong Qi. 2011. Potential Flood Hazard Due to Urban Expansion in the Karst Mountainous Region of North China. Regional Environmental Change 11: 439-40. [CrossRef]

Zhou, Li-Min. 2012. Social Vulnerability: A New Perspective for the Study of Sociology of Hazards. Journal of Nanjing Normal University (Social Science) 4: 20-28. (In Chinese)

Zhou, Hang. 2014. Redevelopment of Urban Village in Shenzhen. Master's thesis, University of Massachusetts Amherst, Amherst, MA, USA; p. 58. Available online: https://scholarworks.umass.edu/masters_theses_2/58 (accessed on 11 August 2020).

Zhou, Nian-Qing, and Shan Zhao. 2013. Urbanization Process and Induced Environmental Geological Hazards in China. Natural Hazards 67: 797-810. [CrossRef] 
Zhu, Xiao-Yang. 2014. The Urbanization of Matter and the War of the Gods. In Transforming Chinese Cities. Edited by Mark Yaolin Wang, Pookong Kee and Jia Gao. New York: Routledge.

Zubir, Syed Sobri, and Hafiz Amirrol. 2011. Disaster Risk Reduction through Community Participation. WIT Transactions on Ecology and the Environment 148: 195-206. [CrossRef] 